\title{
Kuşak Farklılıklarına Göre Finansal Okuryazarlık Düzeyinin Belirlenmesi: Sağlık Çalışanları Üzerine Bir Araştırma
}

DOI: $10.26466 /$ opus.748393

\author{
Nilüfer Yücedağ Erdinç*- Diler Yaman Kayhaoğlu** \\ *Dr., Mersin/ Türkiye \\ E-Posta: n.yucedagerdinc@gmail.com \\ ORCID: $\underline{0000-0001-9698-4865}$ \\ **Dr. Öğr. Göv., Toros Üniversitesi, Mersin/ Türkiye \\ E-Posta: diler.yaman@toros.edu.tr \\ ORCID: $\underline{0000-0002-8539-0700}$
}

$\ddot{O} z$

Bu çalışmanın amacı finansal okuryazarlı̆̆ın kuşaklar arasında farklılık gösterip göstermediğinin test edilmesidir. Finansal okuryazarlık "bilgi", "tutum" ve "davranış" alt boyutlarıla incelenmiştir. Araştırmanın örneklemini Mersin il merkezinde yer alan 377 eczacı oluşturmakta olup, veriler anket yoluyla toplanmıştır. Çalışmada, değişkenler arasındaki ilişkiyi neden ve sonuç belirlemeden incelemek için bir çerçeve olarak korelasyonel bir araştırma tasarımı benimsenmiştir. Elde edilen verilerin frekans ve yüzde dağılımları hesaplanmış, finansal okuryazarlık düzeyinin demografik özelliklere göre farklılık gösterip göstermediğini incelemek üzere t-testi uygulanmış ve finansal okuryazarlığın alt boyutlar arasındaki ilişkileri test etmek için ise Pearson korelasyon analizi yapılmıştır. Araştırmaya göre; katılımcıların finansal okuryazarlı seviyelerinin yüksek olduğu gözlenmiştir. Finansal davranış ve tutum ve finansal bilgi ölçeği puanlarında X ve Y kuşak kodları değişkeni bakımından farklılık olup olmadığı $t$ testi ile incelenmiş, elde edilen bulgulara göre ölçek ve alt boyutlarının hiç birisinde kuşak kodları değişkeni bakımından istatistiksel olarak anlamlı fark bulunamamıştır. Ayrıca araştırmada finansal davranış ile finansal tutum arasında pozitif ve istatistiksel olarak anlamlı bir ilişki bulunmuş olup aynı zamanda finansal davranış ile temel finansal hesaplama düzeyi arasında korelasyon katsayısinın pozitif olduğu tespit edilmiştir. Çalışmada, katılımciların finansal okuryazarlık düzeyi yüksek bulunmuş olup kuşaklara göre finansal okuryazarlık düzeyi arasında farklılık bulunmamıştır. Farklı kuşaklarda yer alan katılımcıların benzer finansal tutum ve davranış sergiledikleri görülmüş̧ür.

Anahtar Kelimeler: kuşak farklılı̆̆l, finansal okuryazarlık, sağglk sektörü 


\title{
Determining The Financial Literacy Level By Generational Differences: A Study On Healthcare Employees
}

\begin{abstract}
The purpose of this study is to test whether financial literacy differs between generations. Financial literacy was examined with its sub-dimensions- "knowledge", "attitude" and "behavior". The sample of the research consisted of 377 pharmacists in the city center of Mersin, and the data were collected through a questionnaire. Frequency and percentage distributions of the questionnaires were found, $t$ test was applied to examine whether financial literacy levels differ according to demographic features and Pearson correlation analysis was done to test the relationships among the sub-dimensions of financial literacy. According to the reseach, it was observed that the participants' financial literacy levels were high. Whether there was a difference in financial behavior, attitude and knowledge scale scores in terms of the $X$ and $Y$ generation codes variable was examined by $t$ test; according to the findings obtained, no statistically significant difference was found in terms of the generation codes variable in any of the scale and its sub-dimensions. Besides according to the research, there was a positive and statistically significant relationship between financial behavior and financial attitude, and at the same time, the correlation coefficient between financial behavior and basic financial calculation level were found to be positive. In the study, the financial literacy level of the participants was found to be high and there was no difference between the financial literacy level according to the generations. Participants from different generations were found to exhibit similar financial attitudes and behavior.
\end{abstract}

Keywords: generation difference, financial literacy, healthcare sector 


\section{Giriş}

Günümüzde ihtiyaç duyulan krediye erişme ve borçlanma olanaklarının daha kolay hale gelmesine karşın, finansal enstrümanlar giderek daha karmaşık bir hal almakta ve bireylere daha yeni ve daha içerikli finansal ürünler sunulmaktadır. Ancak bireyler finansal kararlar almak için iyi donanımlı mıdır diğer bir ifadeyle bunu yapmak için yeterli finansal okuryazarlığa sahip midir?

Ekonomik İşbirliği ve Kalınma Örgütü (OECD)'nün tanımına göre finansal okuryazarlık, sağlam finansal kararlar vermek ve sonuçta bireysel refahı sağlamak için gerekli farkındalık, bilgi, beceri, tutum ve davranışların bir kombinasyonu olarak tanımlanmaktadır. Diğer bir tanıma göre, bireylerin finansal anlayışıyla etkili ve bilgili kararlar vermesini sağlayan beceri ve bilgi kümesi olarak ifade edilmiştir (Ansong ve Gyensare, 2012, s. 126). Finansal okuryazarlık, bireylere finansal bilgileri anlamaları ve kişisel finansmanlarını kullanabilmesi için bilinçli karar verebilmesi gibi finansal konulardaki anlayış düzeylerinin geliştirilmesine yardım eder (Brushan ve Medury, 2013, s. 155). Finansal okuryazarlık seviyesinde meydana gelen artışın finansal karar vermeyi geliştirdiği bulunmuştur (Agarwalla, Barua, Jacob ve Varma, 2015, s. 101). Daha önce konuyla ilgili yapılan çalışmalar, düşük finansal okuryazarlık seviyesinin tasarruf, borçlanma, yatırım ve emeklilik planlaması gibi kişisel finans konularında problemlere neden olduğunu göstermektedir (Brushan ve Medury, 2013, s. 155). Kişilerin az tasarruf yaptıkları, akıllıca yatırım yapamadıkları ve çoğu zaman borçlu olduklarına dair kantlar bulunmaktadır (Lusardi, 2008, s. 2).

Finansal okuryazar kişiler finansal ürün ve hizmetleri etkin bir şekilde kullanabilirler ve kendileri için uygun olmayan finansal ürünleri kullanmaktan kaçınırlar. Finansal okuryazarlık, finansal hizmetlerin kalitesini artırmaya ve bir ülkenin ekonomik büyümesine ve gelişmesine katkıda bulunmaya yardımcı olması bakımından önem arz etmektedir. Ayrıca finansal okuryazar tüketicilerin, sigorta satın almış olması, yapmış oldukları tasarruflar ve yatırımlarını çeşitlendirmesi zorlu finansal dönemleri kolaylıkla atlatmalarını sağlamaktadır. Aynı zamanda finansal ürün ve hizmetler ile ilgili risk ve getiriyi anlamak için minimum düzeyde finansal okuryazarlık bilgisi olması gerekmektedir (Brushan ve Medury, 2013, s. 155). Bu bağlamda, kuşaklar arasındaki farlılıklar da bireylerin satın alma tercihleri, gelir 
durumları, yaşam tarzları, sosyo-ekonomik yapıları ve finansal ürün ve hizmetlere ulaşma şekilleri arasında farlılıklar ortaya çıkmasına neden olmaktadır (Karaboğa ve Eroğlu Pektaş, 2020, s. 159).

Gelişmekte olan ülkelerdeki bireylerin finansal ürün ve hizmetler ile ilgili konularda karar vermede zorluk yaşamaları ve daha fazla hata yapmaları gelişmiş ülkelerdeki finansal okuryazarlık seviyesinin gelişmekte olan ülkelerdekine göre daha yüksek olmasına neden olmuştur (Brushan ve Medury, 2013, s. 155).

OECD nezdinde kurulan Finansal Eğitime Yönelik Uluslararası İşbirliği (International Network on Financial Education-INFE) 14 ülkeden farklı altyapıya sahip bireylerin finansal bilgi, tutum ve davranışlarını sosyodemografik özelliklere göre incelemişlerdir. Çalışma hem ülkeler arası hem de ulusal çapta yapılmış olup araştırmaya dahil edilen her bir ülkede büyük oranda finansal bilgi düzeyinde eksiklikler tespit edilmiştir. Bununla beraber finansal davranışlar açısından kayda değer bir gelişme ve tutumların geniş ölçüde değişiklik gösterdiği ortaya konulmuştur (Atkinson ve Messy, 2012, s. 3). Türkiye' de ise Türk Ekonomi Bankası (TEB), Boğaziçi Üniversitesi işbirliği ile “Türkiye Finansal okuryazarlık Endeksi"'ni hazırlamıştır. Aynı zamanda Dünya Bankası, Sermaye Piyasası Kurulu (SPK) işbirliği ile "Türkiye Finansal Yeterlilik Araştırması" hazırlanmış ve Türk halkının finansal yeterliliğini ölçmek için 12 bölgeden 3009 yetişkin ile mülakat yapılmıştır. Finansal okuryazarlığı ölçebilmek için OECD'nin dünya genelinde uygulanan modülü kullanılmıştır. Yapılan araştırmanın ön sonuçlarına göre, katılımcıların gelir düzeyi yükseldikçe finansal okuryazarlık seviyesinin arttığı, basit ve bileşik faiz oranı ile ilgili sorulara doğru cevaplama oranının basit bölme işlemi sorularına göre düşük olduğu ortaya konulmuştur(SPK, 2012, s. 1-3).

Ampirik çalışmalar finansal okuryazarlığın finansal davranış üzerinde etkili olduğunu ortaya koymuştur. Lusardi ve Tufano (2009), finansal okuryazarlığı düşük olan bireylerin borçlanma konusunda daha fazla sıkıntı yaşayabileceğini belirtmektedir.

Finansal bilgi de dahil olmak üzere herhangi bir konuyla ilgili bilgi düzeyi, yaş, cinsiyet, eğitim durumu, medyaya erişim olanakları, yaşanılan yer gibi birçok değişkenle bağlantılıdır (Ansong ve Gyensare, 2012, s. 127). Chen ve Volpe (1998), yaptıkları çalışmada 20 ila 29 yaş ve 40 yaş ve üstü katılımcıların diğer yaş grubundan daha fazla finansal bilgiye sahip olduklarını 
belirtmişlerdir. Agarwal, Driscol, Gabaix ve Laibson (2009), yaşta meydana gelen artışın, pratik yaşam deneyimlerine dayalı bilgi birikimi ile birlikte geldiğini öne sürmüştür. Finansal okuryazarlık, yaşam döngüsünün ortasında yetişkinler arasında zirve yapma eğiliminde olup genellikle gençler ve yaşlılar arasında en düşük düzeydedir ( $X u$ ve Zia, 2012, s. 11). Lusardi vd. (2009) ABD'de yaptıkları çalışmada genç bireyler arasında finansal okuryazarlığın düşük olduğu ve finansal okuryazarlık ile sosyo-demografik özelikler arasında güçlü bir ilişki olduğu saptanmıştır.

Bu kapsamda çalışmada finansal okuryazarlık ile kuşak farlılıkları arasındaki ilişkiler incelenmiştir. Literatür incelendiğinde finansal okuryazarlık ile ilgili öğrenciler, genç çalışanlar, kamu personeli, hane halkı üzerine yapılan çalışmalara ek olarak ülkeler arası farklılıkları da inceleyen çalışmalar olduğu tespit edilmiştir. Yapılan çalışmaların çoğunluğunda finansal okuryazarlığın, tasarruf, borçlanma, bireysel emeklilik ile ilişkisi incelenmiştir (Güler ve Tunahan, 2017, s. 81). Bu çalışmada diğer çalışmalardan farklı olarak kuşaklar arası farklılıklar ile finansal okuryazarlık seviyesi arasında bir ilişki olup olmadığı araştırılmıştır. Günümüzde teknolojinin hızla gelişmesi, finansal ürün ve hizmetlere ilişkin finansal okuryazarlık düzeyinin, kuşaklara göre farklılık göstermesine neden olabilir. Özellikle Türkiye'de konuyla ilgili çalışmaların büyük çoğunluğu üniversite öğrencileri üzerine yapılmıştır (Yücel ve Kuyumcu, 2018, s. 404). Literatür incelendiğinde finansal okuryazarlık ile ilgili yapılan çalışmalarda sağlık çalışanlarına ilişkin bir araştırmaya rastlanılmamıştır. Bu doğrultuda sağlık kesimi çalışanlarından eczacıların finansal okuryazarlık düzeyleri ile kuşak farklılıkları arasındaki ilişkilerin incelenmesi amaçlanmıştır.

\section{Kavramsal Çerçeve}

Çalışmanın bu kısmında finansal okuryazarlığın alt boyutları ile kuşak ve türleri kavramlarına yer verilmiştir. Daha sonra literatürde finansal okuryazarlık ile ilgili yapılan çalışmalar sunulmuştur.

\section{Finansal Okuryazarlığın Alt Boyutları}

Finansal okuryazarlık, OECD INFE anketine göre finansal bilgi, finansal davranış ve finansal tutum olmak üzere üç alt boyutta ele alınmıştır. Çalışmada kullanılan ölçekler bu üç alt boyuta göre analiz edilmiştir. 


\section{Finansal Bilgi}

Finansal okuryazar olarak adlandırılan bir kişinin ana finansal kavramlar hakkında bazı temel bilgilere sahibi olması beklenmektedir. Finansal bilgisi daha yüksek olan bireylerin emeklilik planları yapma olasılıkları daha yüksektir. Finansal bilgiye sahip olmak gerek faiz bilgisi gerekse basit matematiksel hesaplama yapabilmek için önemli olup, finansal planlamanın en güçlü belirleyicisidir (Lusardi, 2008, s. 13). Bu nedenle Atkinson ve Messy (2012), Agarwalla vd. (2015) ve OECD (INFE) anketleri temel alınarak oluşturulan ankette bilgi düzeyini test eden 9 adet soru yer almaktadır. Genel olarak hesaplama, faiz bilgisi (paranın zaman değeri), enflasyon ve getiri ilişkisi, enflasyon ve fiyatlama, riski dağıtmada çeşitlendirmenin rolünü ölçmek için aşırı karmaşık olmayan ve uzman bilgisi gerektirmeyen sorular farklı zorluk seviyelerinde ve çeşitli finansal konuları kapsayacak şekilde oluşturulmuştur. Katılımcıların verdikleri doğru cevap sayısı dikkate alınarak finansal bilgi puanı yaratılmıştır. Stango ve Zinman (2007), Lusardi ve Tufano (2009), Agarwal vd. (2009), finansal bilgi ile finansal karar verme arasında pozitif ilişki olduğunu belirtmiştir.

\section{Finansal Davranıș}

Bireylerin davranış şekilleri, finansal refahları üzerinde önemli bir etkiye sahiptir. Bu nedenle finansal okuryazarlık ölçümünde davranışların etkilerinin ortaya konulması önemlidir. Finansal davranışı ölçmek için katılımc1lara günlük yaşamlarında para ile ne kadar ilgili olduklarına dair sorular yöneltmiştir. Katılımcıların faturalarını zamanında ödeyip ödeyemedikleri, ürün ve harcamaların karşılanabilirliliğini değerlendirmeleri, uzun vadeli finansal planlama uygulayabildikleri, finansal ürünleri değerlendirebildikleri, tasarruf ve borçlanma alışkanlıklarına ilişkin 9 soru yer almıştır.

\section{Finansal Tutum}

Tutumlar ve tercihler, finansal okuryazarlık üzerinde önemli etkiye sahiptir. Örneğin kısa vadedeki isteklerini önemseyen bireylerin, uzun vadeli plan yapmayı ya da acil durumlar için tasarrufu tercih etme olasllıkları daha düşük olabilir. Finansal tutuma ilişkin üç ifade ile para ve gelecek için planları ölçülmeyi amaçlanmıştır. Bu doğrultuda katılımcıların finansal tutumu, 
planlama ve tasarruf eğilimleri ile tüketme eğilimi derecesini belirlemek için 3 madde kullanılarak ölçülmüştür.

\section{Kuşak Türleri}

Kuşak kavramı ilk kez Auguste Comte tarafından 1830-1840 yıllarında bir toplumun sosyal olarak ilerlemesinin kuşakların kendi dönemlerinde kazandıkları tecrübeleri kendisinden sonra gelen kuşağa aktararak oluşturacağını ifade etmesiyle ortaya atılmıştır (Latif ve Serbest, 2014, s. 136). Kuşak kavramı bir grup insanın doğum yıllarının kronolojik zaman aralığına dayanan sınıflandırılması olarak tanımlanmaktadır. Kuşaklar, sosyal, toplumsal ve ekonomik değişimler ile birlikte deneyim sahibi olurlar. Bu deneyimler ve koşullar, kuşağı etkileyerek düşüncelerin, değerlerin ve inançların oluşmasını sağlar (Pendergast, 2009, s. 507). Bununla birlikte kuşaklar bulundukları yıllarda var olan olaylar ve koşullar tarafından şekillenerek tutum ve davranışlarını olgunlaştırırlar (Howe ve Strauss, 2007, s. 40). II. Dünya Savaşı'ndan sonra ortaya çıkan kuşaklar sırasıyla, sessiz kuşak, baby Boomers, X kuşağı, Y kuşağı ve Z kuşağı olarak sınıflandırılmaktadır.

\section{Kuşă̆ı' nın Tanımı Ve Özellikleri (1965-1979)}

X kuşağındaki bireyler 2020 yılı itibariyle 40 ile 55 yaş arasında olan bireyleri kapsamaktadır. Bu kuşaktaki bireyler rekabetçi ve sonuç odaklıdır. $\mathrm{X}$ Kuşağı üyelerinin en belirgin karakteristik özellikleri arasında çalışmak, kazanmak, başarılı olmak sayılmaktadır. Bununla birlikte iş hayatında da bu şekilde motive olmaktadırlar (Yıldız, 2017, s. 219). Bu kuşak kendinden önceki Baby Boomers olarak adlandırılan kuşağın çocuklarıdır. X Kuşağı üyeleri, toplumsal düşüncelerin sosyalizmden liberalizme geçiş yaptığı ve değiştiği iki farklı dönemin tanı̆̆ı olduklarından "Geçiş Dönemi Çocukları" olarak da adlandırılmaktadır (Fettahlığlu veSünbül, 2015, s. 27). X kuşağını kendisinden önce gelen (sessiz kuşak ve baby boomer) kuşaklardan ayıran en önemli özellik, internetin gelişmesi ile birlikte küresel erişimin meydana gelmesi ve bunun sonucunda da bilgili bir kuşağın ortaya çıkmasıdır. (Kicheva, 2017, s. 109). X kuşağı üyeleri için uygun etiket "bağımsız" olmalarıdır. İnternetin gelişmesi $X$ kuşağı üyelerine kendine güvenen ve değişime uyarlanabilir olmayı sağlamıştır. Aynı zamanda X kuşağı, örgütün hedefleri 
için çalışırken aynı zamanda kendi hedefleri için de çalışmak ister (Fernandez, 2009, s. 4).

\section{Y Kuşağı'nın Tanımı Ve Özellikleri (1980-2000)}

Y Kuşağı üyeleri 2020 yılı itibariyle 20 ile 40 yaş arasında dünyanın ilk küresel kuşağıdır. Bu kuşak Milenyum Kuşağı, Gelecek Kuşak, www Kuşağı, Dijital Kuşak, Net Kuşağı, Neden Kuşağı (Gen Why), Sonrakiler (Nexters) veya Patlama Kopyası (Echo Boomers) olarak da adlandırılmaktadırlar. Bebek Patlaması kuşağındaki doğum oranlarındaki artışa benzer şekilde bu kuşakta da doğum oranları artmıştır (Ekşili ve Antalyalı, 2017, s. 90).Bu kuşağın Y kuşağı olarak adlandırılmasının nedeni sorgulayıcı özelliklerinden dolayı " $Y$ " harfinin "neden" anlamina gelen İngilizce "WHY" kelimesinden türetilmesidir. Aynı zamanda $Y$ kuşağı teknolojiyi yakından takip eden, başarıyı hedefleyen, takım çalışmasına inanan ve kendilerini geliştirmeye odaklı bireylerden oluşmaktadır (Göktaş, 2016, s. 375). X kuşağı ile arasındaki temek farklılıklardan biri, Y kuşağı görevini bitirmek için çevrim içi olur ve görevini tamamladıktan sonrada etrafıyla iletişimde kalmaya devam ederken, $\mathrm{X}$ kuşağı bir görevi bitirmek için çevrimiçi olup ardından işinden uzaklaşmasıdır (Keleş, 2011, s. 130). Aynı zamanda Y kuşağı, yeni gelişen teknolojinin nasıl çalıştı̆̆ konusunda bilgiyle donanımlı olduklarından diğer nesillere göre daha hızlı kararlar almaktadır (Karlsson, Kälvehed ve Sköld, 2014, s. 25). Y kuşağının kariyerlerinden bekledikleri ile ilgili beş ana tema; iş / yaşam dengesi, iyi ücret ve faydalar, ilerleme fursatları, anlamlı iş deneyimleri ve besleyici bir çalışma ortamı olarak belirlenmiştir (Kranenberg, 2014, s. 12).

\section{Bebek Patlaması Kuşağı Tanımı ve Özellikleri (1946-1964)}

Bebek patlaması kuşağı1946-1964 yılları arasında doğan ve 2020 yılı itibariyle 56-74 yaş aralığındaki bireylerden oluşan kuşak olarak tanımlanmaktadır. İkinci Dünya Savaşı sonrası doğum oranlarının sayıca fazlalaşması, bebek patlaması olarak tanımlanmaktadır. Bu kuşağın karakteristik özellikleri; kadın-erkek eşitliği, ırk ayrımına karşı mücadele ve çevreye duyarlı olmak olarak tanımlanmaktadır. Aynı zamanda uzun saatler boyunca çalışmak, iyimserlik, idealist olmak, rekabetçilik, yüksek başarı duygusu ve otoriteye 
bağlılık öne çıkan özellikleridir. Çalışma yaşamında bebek patlaması kuşağı üyeleri, takım çalışmasına değer vermektedirler (Aydın ve Başol, 2014, s.3).

\section{Literatür Taraması}

Finansal okuryazarlık konusunda yapılan birçok çalışmada bireylerin düşük finansal bilgi düzeyine sahip olduğu saptanmıştır. Finansal bilgi seviyesinin düşük olması emeklilik planları, borçlanma davranışları ve hisse senedi sahipliği gibi finansal konularla yakından ilişkilidir (Agarwalla vd. 2015, s. 101). Finansal okuryazarlık ile ilgili yapılan çalışmaların çoğunluğu üniversite öğrencilerinin finansal planlaması ile ilgili olup, ampirik kantlar çoğu öğrencinin harcamalarını planlama konusunda başarısız olduğunu belirtmektedir (Ansong ve Gyensare, 2012, s. 127).

Demografik özellikler ile finansal okuryazarlık arasındaki ilişkiyi inceleyen araştırmacilar, finansal okuryazarlık seviyesi ile cinsiyet, eğitim, gelir durumu ve tecrübe arasında güçlü bir ilişki olduğunu ortaya koymuştur (Al-Tamimi ve Kalli, 2009, s. 503).

Cinsiyet, finansal okuryazarlık üzerinde önemli bir etkiye sahiptir. Lusardi ve Mitchell (2008), Al-Tamimi ve Kalli (2009), Fletschner ve Mesbah (2011), yapmış olduğu çalışmada kadınların erkeklere göre finansal olarak daha az bilgiye sahip olduğunu, Swamy (2014) ise aile içerisinde verilen finansal kararlarda kadınların katılımcı olmaları durumunda aile bütçesinde artış meydana geldiğini ortaya koymuştur. Chen ve Volpe (2002), finansal okuryazarlıktaki cinsiyet farklılıklarına katkıda bulunan güven ve risk almayı ilişkilendirmiştir. Lim, Teo ve Loo, (2003) tutum, bilgi ve genel davranış gibi konularda cinsiyet farklılıklarının çocukluk dönemindeki farklı finansal sosyalizasyondan kaynaklandığını belirtmektedir.

Bazı ülkelerde yapılan alan araştırmaları, gençler de dahil olmak üzere önemli sosyo-ekonomik gruplar arasında düşük düzeyde finansal okuryazarlık olduğunu öne sürmüştür. Teorik modeller gelir, eğitim ve cinsiyete dayalı bazı sosyo-ekonomik grupların finansal okuryazarlık düzeylerinin düşük olabileceğini ileri sürmektedir (Agarwalla vd. 2015, s. 102).

Al-Tamimi ve Kalli (2009) Birleşik Arap Emirlikleri'ndeki finansal yatırımcların finansal okuryazarlık seviyesini inceledikleri çalışmasında, yaş, gelir ve meslek değişkenleri ile finansal okuryazarlık arasında anlamlı bir ilişki olmadığı buna karşın, cinsiyet ve eğitim seviyesi ile finansal okurya- 
zarlık arasında bir ilişki olduğu sonucunu elde etmiştir. Araştırmada ayrıca finansal okuryazarlığın bireylerin yatırım kararların etkilediği belirtilmiştir.

Lusardi ve Mitchell (2007)'e göre ekonomi ya da finans alanlarında eğitim gören bireylerin ileriki yaşamlarında daha yüksek seviyelerde finansal okuryazarlık gösterme olasılıkları daha yüksektir. Sahip oldukları bu finansal bilgileri, finansal okuryazarlığın finansal davranış üzerindeki etkisini değerlendirmek üzere ilerleyen dönemlerde kullanırlar.

Lusardi ve Mitchell (2011), finansal okuryazarlı̆̆ın nedenlerini ve sonuçlarını incelemek için 8 ülkeyi dahil ettiği çalışmasında yaş ve cinsiyetin ülkeler arasındaki finansal bilgiyi etkileyen en önemli unsur olduğunu ortaya koymuştur. Yaşlı nüfusun ortalamanın altında finansal okuryazar olduğu sonucunun yanı sıra kadınların erkeklere göre finansal okuryazarlık seviyesinin daha düşük olduğu tespit edilmiştir. Aynı zamanda finansal açıdan bilgi düzeyi yüksek olanların emeklilik planları yapma olasılığının daha yüksek olduğu belirtilmiştir.

Agarwalla vd. (2015) yaptıkları çalışmada Hindistan'da çalışan genç nüfusun finansal bilgi, davranış ve tutumlarını incelemişlerdir. OECD INFE anketinden yararlandıkları çalışmada standart sosyo-demografik özelliklerin Hindistan'daki finansal okuryazarlık üzerindeki etkisinin diğer ülkelerdeki sonuçlarla benzerlik gösterdiği saptanmıştır. Gerek kadınlar gerekse erkeklerin finansal bilgilerini geliştirmesi gerektiğine ek olarak erkeklerin finansal tutumunu, kadınların ise finansal davranışlarını iyileştirmesine odaklanılması gerektiğini belirtmişlerdir.

Danışman, Sezer ve Gümüş (2016), iktisadi ve idari bilimler fakültesi öğrencilerinin finansal okuryazarlık düzeyini belirlemeyi amaçlayan çalışmasında, katılımciların temel düzeyde finansal okuryazar oldukları, ileri düzeyde ise finansal okuryazarlık seviyesinin düşük olduğunu ortaya koymuşlardır.

Şahin ve Barış (2017) yaptıkları çalışmada kamu çalışanlarının okuryazarlık seviyesini ve finansal okuryazarlığın tasarruf davranışlarına olan etkisini incelemiş̧lerdir. Araştırma sonuçlarına göre yaş, gelir, finansal gelişmeleri takip edilmesi ile temel/ileri düzey okuryazar olma, çalışanların tasarruf davranışlarını pozitif yönde etkilemektedir.

Güler ve Tunahan (2017) hane halkının finansal okuryazarlık düzeylerini belirlemek ve demografik özelliklere etkisini incelemek amaciyla Sakarya ilinde 453 finansal tüketiciye uyguladıkları anket sonucunda hane halkının 
çoğunlukla finansal okuryazarlık seviyesinin düşük olduğu ve tasarruf davranışı üzerinde finansal okuryazarlığın etkili olduğu sonucunu ortaya koymuşlardır.

Er ve Çetintaş (2018) finansal okuryazarlık seviyesini araştırmak amaciyla Artvin ilinde bulunan bir işletmedeki 298 işçiye anket çalışması yapmışlardır. Çalışmaya göre günlük iş ve işlemler açısından finansal okuryazarlık seviyesi yüksek olan işçilerin, gelecekteki tasarruf eğilimlerine ilişkin planlamalarında yetersiz seviyede bilgi, tutum ve davranışa sahip oldukları sonucu elde edilmiştir.

Yücel ve Kuyumcu (2018), finansal okuryazarlı̆̆ın ülke ekonomisindeki yeri ve finansal okuryazarlık düzeyinin tespit edilmesine yönelik Bursa İli'nde yaptıkları çalışmalarında; yaş arttıkça finansal okuryazarlık seviyesinin azaldığı, cinsiyet farkının finansal okuryazarlık üzerinde çok etkili olmadığı ve ankete katılanların yatırımdan ziyade borç yönetimi, tasarruf ve emeklilik konularına önem verdiği sonuçlarını elde etmişlerdir.

Doğan (2019), Türkiye'deki bireylerin finansal okuryazarlık düzeyini belirlemek için 25 farklı ilde 2300 kişiye anket uygulayarak yaptığı çalışmasında, genel olarak finansal okuryazarlık başarı seviyesinin \%50'nin üzerinde olduğunu ve en düşük başarı oranının faiz ve matematik hesaplamasında olduğunu ortaya koymuştur. Aynı zamanda erkek katılımcıların finansal okuryazarlık seviyesinin kadınlara oranla daha yüksek olduğu tespit edilmiştir.

\section{Yöntem}

$\mathrm{Bu}$ araştırmanın temel amacı sağlık çalışanları arasındaki kuşak farklılıkları ile finansal okuryazarlık seviyesi arasındaki ilişkiyi incelemektir. Bu doğrultuda Mersin ili merkezinde yer alan 377 eczacıya anket çalışması uygulanmış, araştırma için toplam 200 anket analize tabi tutulmuştur. Finansal okuryazarlık anketi için OECD nezdinde kurulan Finansal Eğitime Yönelik Uluslararası İşbirliği (International Network on Financial Education-INFE) ve Atkinson ve Messy (2012) tarafindan oluşturulan anket soruları temel alınmış, anket çalışmasındaki puanlama ve sınıflandırma yöntemi bu çalışmalara dayandırılmıştır.

Anket formu dört alt başlıktan oluşmaktadır. İlk alt başlıkta katılımcıların sosyo-demografik özelliklerine ilişkin sorular yer almaktadır. İkinci alt 
başlıkta katılımcıların finansal bilgi düzeyini ölçmek amacıyla temel ve ileri düzey çoktan seçmeli matematik soruları ile temel finansal kavramlar ile ilgili doğru/yanlış soruları yer alırken üçüncü alt başlıkta, katılımcıların finansal davranışlarına ilişkin 5'li likert ölçekli katılım soruları sorulmuştur. Son kısımda ise finansal tutumu ölçmek için benzer şekilde 5'li likert ölçekli 3 adet katılım sorusu yer almaktadır.

Cronbach alpha katsayısı ile anket sorularının güvenilirliği kontrol edilmiş ve hesaplanan cronbach alpha değeri $(0,92)$ ölçeğin güvenilir olduğunu ortaya koymuştur. Güvenilirlik analizi, finansal kavramlar, finansal davranış ve tutumları içeren 5'li likert ölçekli sorulara uygulanmış, demografik değişkenler analize dahil edilmemiştir. Söz konusu örneklemdeki verilerin analizi için SPSS (Statistical Packages for the Social Sciences) 21.0 paket programı kullanılarak katılımcların demografik özelliklerini incelemek için frekans ve yüzde dağılımları hesaplanmış, finansal okuryazarlık düzeyinin demografik özelliklere göre farklılık gösterip göstermediğini incelemek üzere t-testi uygulanmış ve finansal okuryazarlığın alt boyutları arasındaki ilişkileri test etmek için ise Pearson korelasyon analizi yapılmıştır. Verilerin anlamlılık düzeyi 0.05 olarak alınmıştır.

Araştırmaya ait hipotezler aşağıda yer almaktadır:

- $\mathrm{H}_{1}$ : Finansal tutum ve davranışlar ile $X$ kuşağı arasında farklılık vardır

- $\mathrm{H}_{2}$ : Finansal tutum ve davranışlar ile Y kuşağı arasında farklılık vardır

- $\mathrm{H}_{3}$ :Finansal bilgi düzeyi ile $\mathrm{X}$ kuşağı arasında farklılık vardır

- H4: Finansal bilgi düzeyi ile Y kuşağı arasında farklılık vardır

- H5: Finansal davranış ve tutum ile finansal bilgi puanı arasında ilişki vardır.

\section{Bulgular}

Araştırmada elde edilen bulgular, demografik özelliklere ilişkin bulguşar olmak üzere finansal okuryazarlık düzeyine ilişkin genel bulgulara ek olarak finansal bilgi, tutum ve davranış değişkenleri ile kuşak kodları arasındaki ilişkiyi gösteren bulgular olarak sunulmuştur.

\section{Katılımcılarn demografik özelliklerine ilişkin bulgular}

Katılımcıların demografik özelliklerini gösteren bulgular Tablo 1'de özetlenmiştir. 
Tablo 1. Demografik Değişkenlere İlişkin Frekans Dağılımı

\begin{tabular}{lll}
\hline Değişkenler & Frekans & Yüzde \\
\hline Cinsiyet & & \\
\hline Kadın & 94 & 47,0 \\
Erkek & 106 & 53,0 \\
\hline Yaş & & \\
\hline BB & 17 & 8,5 \\
$X$ & 79 & 39,5 \\
Y & 104 & 52,0 \\
\hline Medeni durum & & \\
\hline Evli & 152 & 76,0 \\
Bekar & 48 & 24,0 \\
\hline Eğitim & & \\
\hline Lisans & 164 & 82,0 \\
Lisansüstü & 36 & 18,0 \\
\hline Gelir & & \\
\hline 10.00 TL'den az & 85 & 42,5 \\
$10.000-30.000$ & 104 & 52,0 \\
30.000 TL'den çok & 11 & 5,5 \\
\hline
\end{tabular}

Elde edilen bulgulara göre ankete katılanların \%47'si kadın, \%53'ü erkektir. Katılımcların \%52'si Y kuşağında yer alırken, en az katılımc \%8,5 ile BB kuşağına aittir. Katılımcıların medeni durumlarına bakıldığında, evli katılımcıların oranı \%76 ve bekâr katılımcıların oranı \%24 olduğu ayrıca katılımcların \%82'sinin lisans, \%18'nin ise lisansüstü eğitime sahip oldukları gözlemlenmiştir. Aylık gelir durumu incelendiğinde ise; katılımcıların $\% 42,5^{\prime}$ inin 10.000 TL'den az, \%52'sinin 10.000-30.000 TL aras1 ve \%5,5'inin 30.000 TL'den fazla aylık gelire sahip olduğu görülmektedir.

Finansal okuryazarlık ölçümünde OECD INFE çalışması temel alınarak aşağıdaki kodlama sistemine göre anket yanıtları değerlendirilmiştir. Buna göre;

1. Temel finansal hesaplama ve kavramlarla ilgili sorulara verdiği doğru cevap sayısı 6 veya daha az olanlar: Düşük

2. Temel finansal hesaplama ve kavramlarla ilgili sorulara verdiği doğru cevap sayısı 7 veya daha fazla olanlar arasında;

i. finansal davranış ve tutum ölçeği ortalama puanı 3,4'den az olanlar: Orta

ii. finansal davranış ve tutum ölçeği ortalama puanı 3,4 veya daha fazla olanlar: Yüksek, 
olarak değerlendirilmiştir. Verilen her doğru cevap 1 puan, yanlış cevap ise 0 puan olacak şekilde puanlandırılmıştır. Tablo 2'de katılımcıların finansal okuryazarlık durumlarına ilişkin frekans dağılımı yer almaktadır.

\section{Finansal Okuryazarlık Düzeyine İlişkin Tanımlayıcı İstatistikler}

Ankete katılan bireylerin finansal okuryazarlık, tasarruf yapma, finansal araç kullanıma bilgisi ile finansal bilgi düzeylerine ilişkin temel analiz sonuçları aşağıda yer almaktadır.

\begin{tabular}{lcc} 
Tablo 2.Ankete Katılan Bireylerin Finansal & Okuryazarlık & Durumlarn Frekans Dağılımı \\
\hline Finansal okuryazarlık & Sayı & Yüzde \\
Düşük & 20 & 10,0 \\
Orta & 80 & 40,0 \\
Yüksek & 100 & 50,0 \\
Toplam & 200 & 100,0 \\
\hline
\end{tabular}

Tablo 2'de yer alan bilgilere göre, katılımcıların finansal okuryazarlık oranlarına bakıldığında, ankete katılan eczacıların \%10'unun finansal okuryazarlık seviyesinin düşük, \%40'ının orta ve \%50'sinin ise yüksek olduğu gözlemlenmiştir.

Ankete katılan bireylerin tasarruf yapma duruma ilişkin frekans dă̆ılımları Tablo 3'de gösterilmiştir.

Tablo 3. Tasarruf Yapma Göre Durumlarna İlişkin Frekans Dağılımı

\begin{tabular}{lll}
\hline Tasarruf & Frekans & Yüzde \\
Evet & 157 & 78,5 \\
Hayır & 43 & 21,5 \\
\hline
\end{tabular}

Katılımcıların tasarruf yapma durumları incelendiğinde, elde edilen bulgulara göre katılımcıların \%78,5'inin tasarruf yaptığı, \%21,5'inin ise tasarruf yapmadığ1 gözlemlenmiştir.

Ankete katılan bireylerin kullandıkları finansal araçlara ilişkin frekans dağılımları Tablo 4'de yer almaktadır.

Tablo 4. Finansal Araç Kullanım Bilgisine İlişkin Frekans Dağılımı

\begin{tabular}{lll}
\hline & Frekans & Yüzde \\
\hline Hisse senedi/tahvil/hazine bonosu & 23 & 11,5 \\
Repo & 5 & 2,5 \\
Banka mevduatı & 65 & 32,5 \\
Altın & 92 & 46,0 \\
Döviz & 80 & 40,0 \\
Bireysel emeklilik fonu & 101 & 50,5 \\
Hiçbiri & 37 & 18,5 \\
\hline
\end{tabular}


Tablo 4'de katılımcların kullandıkları yatırım araçları durumuna göre frekans dağılımı verilmiştir. Elde edilen bulgulara göre katılımcıların $\% 11,5^{\prime}$ inin hisse senedi/tahvil/hazine bonosu, \%2,5'nin repo, \%32,5'inin mevduat, \%46,0'ının altın, \%40'ının döviz, \%50,5'nin emeklilik fonu gibi yatırım araçlarını kullandıkları gözlemlenirken \%18,5'nin ise bu finanssal araçlardan hiçbirini kullanmadıkları gözlemlenmiştir.

Tablo 5. Kredi Kartı Ve E-Bankacılık İşlemleri Kullanma Durumuna İlişkin Frekans Dağılımı

\begin{tabular}{lll}
\hline Kredi kartı ve E-bankacilı & Frekans & Yüzde \\
Yalnızca kredi kartı & 12 & 6,0 \\
Yalnıca E-Bankacilı & 8 & 4,0 \\
Her İkisini de kullanıorum & 178 & 89,0 \\
Her İkisini de kullanmıyorum & 2 & 1,0 \\
\hline
\end{tabular}

Ankete katılan bireylerin kredi kartı ve e-bankacılık işlemlerini kullanma durumlarına ilişkin frekans dağılımları Tablo 5'te verilmiştir. Elde edilen bulgulara göre katılımcların \%6'sının yalnız kredi kartı, \%4'ünün yalnızca e-bankacılık işlemlerini kullandıkları saptanmıştır. Ankete katılan eczacıların \%89'u hem kredi kartı hem de e-bankacilık kullanmayı tercih ederken, \%1'nin ise hem kredi kartı hem de e-bankacılık kullanmadıkları tespit edilmiştir.

Tablo 6. Temel Finansal Hesaplama ve Kavramlar Hakkındaki Bilgi Durumlan Frekans Dağılımı

\begin{tabular}{lllll}
\hline & \multicolumn{2}{l}{ Doğru cevap verenler } & \multicolumn{2}{l}{ Yanlış cevap verenler } \\
& Frekans & Yüzde & Frekans & Yüzde \\
\hline Basit faiz & 180 & 90,0 & 20 & 10,0 \\
Bileşik faiz & 147 & 73,5 & 53 & 26,5 \\
Paranın zaman değeri & 176 & 88,0 & 24 & 12,0 \\
Faiz oranı ile kredi kullanımı ilişkisi & 189 & 94,5 & 11 & 5,5 \\
Enflasyon tanımı & 195 & 97,5 & 5 & 2,5 \\
Risk ve getiri & 176 & 88,0 & 24 & 12,0 \\
Çeşitlendirme & 181 & 90,5 & 19 & 9,5 \\
KDV & 189 & 94,5 & 11 & 5,5 \\
Hisse senedi & 138 & 69,0 & 62 & 31,0 \\
\hline
\end{tabular}

Ankete katılan bireylerin temel finansal kavramlar hakkındaki bilgi durumları frekans dağılımı Tablo 6'da verilmiş̧ir. Elde edilen bulgulara göre katılımcıların, hisse senedi kavramı hariç diğer kavram bilgilerinde finansal hesaplamaya göre daha başarılı oldukları görülmektedir. 
Araştırmanın bu kısmında katılımcıların kuşak farklılıkları bakımından finansal okuryazarlık düzeyleri arasında anlamlı bir farklılık olup olmadığı incelenmiştir. Finansal okuryazarlık finansal bilgi, finansal davranış ve finansal tutum olarak üç alt boyutta incelenmiş ve sonuçlar Tablo 7 ve Tablo 8 'de sunulmuştur. Tablo 7'de finansal davranış ve tutum düzeyinin kuşaklara göre farklılığını araştırmak amacıyla yapılan analiz sonuçları yer almaktadir.

\section{Finansal Davranış ve Tutum Ölçeği ile Kuşak Kodlarına İlişkin Bilgiler}

Ankete katılan eczaciların finansal tutum, finansal davranış ile kuşak farklılıkları bakımından benzer olup olmadığına ilişkin bulgular aşağıda özetlenmiştir.

Tablo 7. Finansal Davranış Ve Tutum Ölçeği Puanlarının Kuşak Kodlan Değişkeni Bakımından Incelenmesi

\begin{tabular}{lllllll}
\hline & Kuşak kodları & $\mathrm{N}$ & Ort. & Std. Sapma & $\mathrm{t}$ & $\mathrm{p}$ \\
\hline Finansal davranış & $\mathrm{X}$ & 79 & 3,43 & 1,096 & 0,187 & 0,852 \\
& $\mathrm{Y}$ & 104 & 3,40 & 1,025 & & \\
\hline Finansal tutum & $\mathrm{X}$ & 79 & 2,24 & 0,878 & $-1,532$ & 0,127 \\
& $\mathrm{Y}$ & 104 & 2,46 & 0,951 & & \\
\hline Finansal davranış ve tutum & $\mathrm{X}$ & 79 & 3,13 & 0,878 & $-0,234$ & 0,815 \\
& $\mathrm{Y}$ & 104 & 3,16 & 0,872 & & \\
\hline
\end{tabular}

Finansal davranış ve tutum ölçeği puanlarında kuşak kodları değişkeni bakımından farklılık olup olmadığ $\mathrm{t}$ - testi ile incelenmiştir. Elde edilen bulgulara göre ölçek ve alt boyutlarının hiç birisinde kuşak kodları değişkeni bakımından istatistiksel olarak anlamlı fark bulunamamıştır. Tabloya bakıldığında $p>0.05$ olduğu tespit edilerek $X$ ve $Y$ kuşaklarının finansal tutum ve davranışları arasında anlamlı olmayan bir ilişki olduğu görülmektedir. Buna göre $\mathrm{H}_{1}$ ve $\mathrm{H}_{2}$ hipotezleri reddedilmiştir.

Tablo 8. Temel Finansal Bilgi Ölçeğinin Kuşak Kodlan Değişkeni Bakımından İncelenmesi

\begin{tabular}{lllllll}
\hline & Kuşak kodları & $\mathrm{N}$ & Ort. & Std. Sapma & $\mathrm{t}$ & $\mathrm{p}$ \\
\hline Temel finansal hesaplama & $\mathrm{X}$ & 79 & 2,42 & 0,709 & $-1,306$ & 0,193 \\
& $\mathrm{Y}$ & 104 & 2,55 & 0,637 & & \\
\hline Temel finansal kavram & $\mathrm{X}$ & 79 & 5,48 & 0,731 & 1,733 & 0,085 \\
& $\mathrm{Y}$ & 104 & 5,28 & 0,818 & & \\
\hline Finans bilgi puanı & $\mathrm{X}$ & 79 & 7,90 & 1,093 & 0,462 & 0,644 \\
& $\mathrm{Y}$ & 104 & 7,83 & 0,999 & & \\
\hline
\end{tabular}


Finansal bilgi ölçeği puanlarında kuşak kodları değişkeni bakımından farklılık olup olmadığı t-testi ile incelenmiştir. Elde edilen bulgulara göre ölçek ve alt boyutlarının hiç birisinde kuşak kodları değişkeni bakımından istatistiksel olarak anlamlı bir fark bulunamamıştır. Tabloya bakıldığında $p>0.05$ olduğu tespit edilerek $X$ ve $Y$ kuşaklarının finansal bilgi düzeyi arasında anlamlı olmayan bir ilişki olduğu görülmektedir. Buna göre $\mathrm{H}_{3}$ ve $\mathrm{H}_{4}$ hipotezleri reddedilmiştir.

Tablo 9. Finansal Okuryazarlık Alt Gruplarının Diğer Demografik Değişkenler Bakımindan İncelenmesi

\begin{tabular}{|c|c|c|c|c|c|c|c|}
\hline \multirow[t]{2}{*}{ Değişkenler } & \multirow{2}{*}{$\begin{array}{l}\mathrm{N} \\
200\end{array}$} & \multicolumn{2}{|c|}{ Finansal Bilgi } & \multicolumn{2}{|c|}{ Finansal Davranış } & \multicolumn{2}{|c|}{ Finansal Tutum } \\
\hline & & ortalama & $\mathrm{p}$ & ortalama & $\mathrm{p}$ & ortalama & $\mathrm{p}$ \\
\hline \multicolumn{8}{|l|}{ Cinsiyet } \\
\hline Kadın & 94 & 7,69 & & 3,53 & & 2,38 & \\
\hline Erkek & 106 & 8,00 & 0,034 & 3,30 & 0,129 & 2,33 & 0,704 \\
\hline \multicolumn{8}{|l|}{ Medeni Durum } \\
\hline Evli & 152 & 7,95 & & 3,35 & & 2,30 & \\
\hline Bekar & 48 & 7,56 & 0,024 & 3,59 & 0,183 & 2,51 & 0,181 \\
\hline \multicolumn{8}{|l|}{ Eğitim } \\
\hline Lisans & 164 & 7,87 & & 3,43 & & 2,36 & \\
\hline Lisansüstü & 36 & 7,81 & 0,751 & 3,29 & 0,470 & 2,34 & 0,938 \\
\hline \multicolumn{8}{|l|}{ Gelir } \\
\hline 10000 TL den az & 85 & 7,75 & & 3,44 & & 2,40 & \\
\hline $10000-30000 \mathrm{TL}$ aras 1 & 104 & 7,88 & 0,386 & 3,41 & 0,820 & 2,35 & 0,723 \\
\hline
\end{tabular}

Yapılan t-testi analizine göre, ankete katılan eczacıların finansal tutum ve davranışlarının, cinsiyete göre istatistiksel olarak anlamlı olmadığı buna karşın, finansal bilgi düzeyinin cinsiyete göre farklılık gösterdiği sonucu elde edilmiştir. Buna göre ortalamalar incelendiğinde erkeklerin finansal bilgi puanı ortalamasının kadınlara göre daha yüksek olduğu görülmektedir. Finansal davranış ve tutum ölçeğinin medeni durum değişkeni bak1mindan farklılık göstermediği fakat finansal bilgi puanı ile medeni durum arasında istatistiksel olarak anlamlı farklılık olduğu saptanmıştır. Diğer bir ifadeyle, ortalamalar incelendiğinde evli olan katılımcıların finansal bilgi puanı ortalamasının daha yüksek olduğu görülmektedir. Son olarak eğitim ve gelir değişkenleri bakımından finansal bilgi, finansal davranış ve tutum ölçeklerinin hepsinde istatistiksel olarak anlamlı farlılık bulunamamıştır. Diğer bir ifadeyle, ankete katılan bireylerin finansal okuryazarlık düzeyi, gelir ve eğitim değişkenlerine göre farklılık göstermemektedir. 


\section{Finansal Bilgi Düzeyi ile Finansal Davranış ve Tutum Arasındaki İlişkiler}

Son olarak katılımcıların finansal bilgi düzeyi ile finansal davranış ve tutumları arasındaki ilişkiyi incelemek için Pearson kolerasyon analizi yapılmış, sonuçlar Tablo 10'da gösterilmiştir.

Tablo 10. Finansal Davranış Ve Tutum İle Finansal Bilgi Arasındaki Korelasyon Katsayıları

\begin{tabular}{llllll}
\hline & Finansal davranış & Finansal tutum & Finansal bilgi & hesap1 & hesap2 \\
Finansal davranış & 1 & & & & \\
Finansal tutum & $\mathbf{2 4 2}$ & 1 & & & \\
Finansal bilgi & $\mathbf{1 3 3}$ &,- 045 & 1 & & \\
Temel finansal hesaplama & $\mathbf{1 6 6}$ & 0,74 &, 631 & 1 & \\
Temel finansal kavram &, 648 & $-0,120$ &, 763 & $-0,019$ & 1 \\
\hline
\end{tabular}

Elde edilen bulgulara göre; ankete katılan bireylerin finansal davranış ile temel finansal hesaplama $(0,166)$ düzeyi arasında pozitif ve anlamlı $(\mathrm{p}<0,05)$ ilişki olduğu tespit edilmiştir. Bu açıdan bakıldığında, literatürde, finansal bilginin genelde finansal refahla tutarlı davranışlara dayanan olumlu sonuçlarının bulunduğu ifade edilmektedir (Atkinson ve Messy, 2012, s. 40). Atkinson ve Messy (2012), yaptıkları çalışmalarında davranış ile bilgi arasında araştırmaya dahil edilen tüm ülkelerde çalışmayla benzer şekilde pozitif ilişki olduğunu belirtmiştir. Uygun finansal ürünleri seçme veya geleceğe yönelik tasarruf etme gibi konularda karar verme kalitesini artırmak için ek bilgilerden yararlanma olasılığının yüksek olması araştırma sonuçlarıyla tutarlıdır. Finansal bilginin geliştirilmesi bireylerin finansal piyasalara daha aktif olarak katılmasına ve olumlu davranışlara neden olabilir. Temel finansal hesaplama yapabilen bireylerin daha uzun vadeli finansal hedeflerini gerçekleştirmek için daha kolay yatırım veya tasarruf yapabildikleri ya da finansal işlerini sıklıkla/kolaylıkla takip edebildikleri söylenebilir. Aynı zamanda potansiyel satın alımlar ya da finansal taahhütlerini yerine getirebilme becerileri gibi konularda daha fazla bilgiye sahip olabilmeleri finansal konulardaki ihtiyaçlarını daha rahat belirlemelerine neden olabilir.

Finansal tutum ile finansal davranış arasındaki $(0,242)$ pozitif anlamlı ilişkiye göre; uzun vadeye yönelik olumlu tutumlar, uzun vadeli hedeflere ulaşmak için tutarlı davranma olasılığını artırmaktadır. Sonuç olarak olumlu finansal tutumların, bireylerin yatırım ve tasarruf yapma, borç kullanımı 
gibi konularda daha uzun vadeli kararlar vermesini destekledikleri ifade edilebilir. Çalışmada elde edilen bu bulgu, Atkinson ve Messy (2012)'nin yaptığı çalışma ile benzerlik göstermektedir.

\section{Tartışma ve Sonuç}

Yeni finansal ürünlerin geliştirilmesi, finansal piyasaların daha karmaşık hale gelmesiyle birlikte politik, demografik ve ekonomik faktörlerdeki değişmelere bağlı olarak finansal okuryazarlığın önemi gün geçtikçe artmaktadır. Finansal sistemdeki gelişmeler tüketicilerin borçlanma ve yatırım davranışlarını etkilemekte ve öncelikle yaş olmak üzere sosyo-demografik yapıda meydana gelen değişmeler tüketicilerin finansal kararlarını etkilemektedir. Bu çalışma, sağlık çalışanlarından olan eczacıların finansal okuryazarlık düzeylerinin kuşaklara göre farklılık gösterip göstermediğini araştırarak, yapılan diğer çalışmalardan farklı bir hedef kitleyi incelemiştir. Bireylerin farklı kuşaklarda yer almasının, finansal bilgi, finansal davranış ve finansal tutumları arasında farklılık yaratıp yaratmayacağı araştırılmış ayrıca diğer demografik değişkenlerin finansal okuryazarlık düzeylerine etkisi analiz edilmiştir.

Yapılan analiz sonuçlarına göre; araştırmaya katılan eczacıların finansal okuryazarlık düzeyinin yüksek olduğu tespit edilmiştir. Aynı zamanda katılımcıların temel finans bilgi düzeyinin, matematiksel hesaplama düzeyine göre yüksek olduğu saptanmıştır. Araştırmanin temel amacı olan kuşak farlılıklarının finansal okuryazarlık düzeyine göre farklılık gösterip göstermediğini belirlemek üzere yapılan analizler çerçevesinde; ankete katılan eczacıların yaşları arasındaki farklılıkların finansal bilgi, tutum ve davranışları bakımından farklılık göstermediği sonucu elde edilmiştir. Bu doğrultuda; farklı kuşaklarda yer alan katılımcılar benzer finansal tutum ve davranışlar sergilemektedir. Öte yandan ankete katılan eczacılar içerisinde erkek katılımcıların kadınlara göre finansal bilgi düzeyinin daha yüksek olduğu ayrıca medeni durum bakımından evli olan katılımcıların finansal bilgi düzeyinin bekar olanlara göre daha fazla olduğu tespit edilmiştir. Son olarak katılımcıların eğitim ve gelir seviyesinin benzer olması, finansal okuryazarlık seviyeleri bakımından farklılık olmamasına neden olabilir.

Sonuç olarak benzer eğitim, gelir ve meslek grubunda yer alan bireylerin finansal okuryazarlık seviyeleri arasında farklılık bulunmayabilir. Litera- 
türde yer alan diğer çalışmaların aksine bu çalışmada ankete katılan eczacıların finansal okuryazarlık seviyesi yüksek bulunmuş, kuşaklara göre finansal okuryazarlık seviyesi arasında bir farklılığa rastlanmamıştır. Diğer bir ifadeyle yaş değişkeni; eğitim, gelir ve meslek değişkenlerinin birbirine benzer olması kaydıyla, finansal okuryazarlık seviyesi üzerinde tek başına farklılık yaratmayabilir. Bu bulgulardan hareketle, ileride farklı sağlık çalışanlarını ya da farklı meslek gruplarını da kapsayacak şekilde benzer çalışmalar yapılarak kuşaklar arasındaki farklılıkların finansal okuryazarlık ile ilişkisi incelenebilir. 


\title{
EXTENDED ABSTRACT
}

\section{Determining The Financial Literacy Level By Generational Differences: A Study On Healthcare Employees}

\author{
Nilüfer Yücedağ Erdinç - Diler Yaman Kayhaoğlu \\ Toros University
}

Financial literacy is ability to understand the finance. Organizationfor Economic Cooperation and Development,International Network on Fnancial Education-OECD INFE) definition of financial literacy is a combination of awareness, knowledge, skill, attitude and behaviour necessary to make sound financial decisions and ultimately achieve individual financial wellbeing (Atkinson and Messy, 2012, p.14). Financial liretacy has become increasingly important for individuals, bankers, governments, employers and other organizations. It provide individulas to develop their overall wellbeing. Nowadays, financial instruments are getting more and more complex and newer and more content financial products are offered to individuals. However, it is not certain that people have sufficient information and equipment to make financial decisions.Therefore, financially literate individuals can use financial products and services effectively and avoid using financial products that are not suitable for them. At the same time, it is necessary to have a minimum level of financial literacy knowledge in order to understand the risk and return related to financial products and services. Differences between generations also cause differences between individuals' purchasing preferences, income states, lifestyles, socio-economic structures and ways of accessing financial products and services.

Generational groups is described as a collective group of people born and raised in a similar location, who have experienced similar historical and social events. People who are from different generations, share common experiences that influence their thoughts and behavior. Generational differences often considers the characteristics and values of each generation. Generations that emerged after World War II are classified as silent generation, 
baby boomers, generation $\mathrm{X}$, generation $\mathrm{Y}$ and generation $\mathrm{Z}$ respectively (Pendergast, 2009, p. 507).

Most of the recent studies consistently indicate that financial litreacy levels are unaccepteably low around the world. Developed countires are more financially literate than developing countries. Also, studies indicate that levels of financial literacy varied with people's income, education, age and gender. Particularyl, women had much lower financial literacy than men (Al-Tamimi ve Kalli, 2009, p. 503).

In this paper, the relationship between financial literacy and generational differences is examined. When the literature is analyzed, it is determined that there are studies examining the differences between countries in addition to the studies on financial literacy related to students, young employees, public personnel and households ect. In this study, unlike other studies, it was investigated whether there is a relationship between intergenerational differences and financial literacy level.

Financial literacy is a combination of awareness, knowledge, skill, attitude and behaviour necessary to make sound financial decisions. According to the study, financial liretacy measures 3 basic financial concepts: financial knowledge, financial behaviours and financial attitute. The financial literacy related data are collected using the OECD INFE questionnaire and this study is based on the OECD INFE questionnare. The first nine questions require basic numeracy skills, time value of money, relationship between inflation and price, risk and return and definitation of stock and financial markets.The second nine questions are about financial behaviours consist in how participants deal with money in their daily life and the last three questions require financial product choice and financial plans. There are also some questions about socio-demographic details of the participants age, gender, income and education levels. Financial knowledge score was created by counting the number of correct answers and each correct answer is given a score of one. Financial behaviour and attitudes questions ask participants about whether they agree or disagree with the statements.

The questonnaires were used in city center of Mersin and the sample of the research consisted of 377 pharmacists, but only 200 participants were returned. The relationship between the financial literacy and generation differences in Mersin is analyzed using Pearson correlation. Besides, frequency and percentage distributions of the questionnaires are found, t-test 
is applied to examine whether financial literacy levels differ according to demographic features. The sample size of the research was calculated at the level of $95 \%$ confidence.

Based on the findings from the other empirical studies and related theory, women would be expected to show lowe levels of financial literacy relative to men. Financial literacy level is found to be affected by marital status. Specifically, married participants have a higher level of financial literacy than single ones.

On the other hand the level of financial literacy among the pharmacists in Mersin is not similar to the literature. But the socio-demographic attributes of financial literacy is broadly similar to the other studies. According to the research, it is concluded that the differences between the ages of the pharmacists participating in the survey do not differ in terms of financial knowledge, attitudes and behaviors. This finding indicates that participants from different generations display similar financial attitudes and behaviors. In other words, age variable; provided that the variables of education, income and profession are similar, they may not make a difference alone on the level of financial literacy.

Further research can be conducted by extending the scope of the study to cover the other healthcare professionals including doctors, nurses. Moreover the study can be extended to compare financial literacy in other citys, countries or sectors.

\section{Kaynakça / References}

Akbulut, Y. (2010). Sosyal bilimlerde SPSS uygulamalar. İstanbul: İdeal Kültür Yayıncllk. Akiş, Y. T. (2005). Sosyal ve kurumsal liderlik. Ceo's Leadership Insights, 21, 1-5.

Akyüz, B. (2012). Hizmetkâr liderlik davranışlarnnn örgütsel adalet, örgütsel vatandaşlık davranıslar ve performans üzerine etkisi: Ĕ̈itim sektörü üzerine bir araştırma. Yayınlanmamış doktora tezi. Gebze Yüksek Teknoloji Enstitüsü, Kocaeli.

Balc, A. (2001). Sosyal bilimlerde araştrma yöntem, teknik ve ilkeler. Ankara: Pegem Yayınclik.

Barbuto, J. E., ve Wheeler, D.W. (2006). Scale development and construct clarification of servant leadership. Group ve Organization Management, 31(3), 300326.

Bayram, N. (2009). Sosyal bilimlerde SPSS ile veri analizi. Bursa: Ezgi Kitabevi. 
Blanchard, K., Blanchard, S. ve Zigarmi, D. (2007). Hizmetkâr liderlik. K. Blanchard (Ed.), Liderlikte Çıtayı Yükseltmek içinde (s. 293-324). İstanbul: Kaizen-Resital Yayınclik.

Büyüköztürk, Ş. (2005). Anket geliştirme. Türk Eğitim Bilimleri Dergisi, 3(2), 133-151.

Büyüköztürk, Ş. (2013). Sosyal bilimler için veri analizi el kitabı. Ankara: Pegem Akademi Yayınclik.

Can, A. (2013). SPSS ile bilimsel araştrma sürecinde nicel veri analizi. Ankara: Pegem Akademi.

Comfrey, A. L. ve Lee, H. B. (1992). A first course in factor analysis. Hillsdale, Nj: Lawrence Erlbaum Associates.

Dennis, R. S. ve Bocarnea, M. (2005). Development of the servant leadership assessment instrument. Leadership ve Organization Development Journal, 26(8), 600615.

Dierendonck, D. V. ve Nuijten, I. (2011). The servant leadership survey development and validation of a multidimensional measure. Journal of Business and Psychology, 26(3), 249-267.

Ekinci, A. (2015). Okul müdürlerinin hizmetkâr liderlik davranışları ölçeğinin geliştirilmesi ve hizmetkâr liderlik davranışlarınn öğretmen görüşlerine göre değerlendirilmesi. Eğitim ve Bilim, 179(40), 341-360.

Ekinci, A. ve Sakız, H. (2020). Handbook of research on positive organizational behavior for improved workplace performance. Servant Leadership Within the Context of Organizational Efficacy. İçinde (s.86-101), IGI Global, Pennsylvania, USA.

Erkorkmaz, U., Etikan, İ., Demir, O., Ozdamar, K. ve Sanisoglu, S. Y. (2013). Doğrulayıc factor analizi ve uyum indeksleri. Türkiye Klinikleri Tpp Bilimleri Dergisi 33(1), 210-223.

Fındıkçı, İ. (2012). Bir gönül yolculuğu hizmetkâr liderlik (3. Baskı). İstanbul: Alfa Basım Yayım Dağıtım.

Gorsuch, R. L. (1997). Exploratory factor analysis: Its role in itemanalysis. Journal of Personality Assessment, 68(3), 532-560.

Greenleaf, R. K. (2002). Focus on leadership. L. C. Spears (Ed.). Essentials of servantleadership (s. 19-26). New York: John Wiley ve Sons, Inc.

Hardin, F. (2003). Impacting texas public schools through a student servant leader model: A case study. Unpublished doctoral thesis, Texas Tech University, Texas.

Izquierdo, I., Olea, J. ve Abad, F.J. (2014). Exploratory factor analysis in validation studies: Use sandre commendations. Psicothema, 26(3), 395-400. 
Laub, J. A. (1999). Assessing the servant organization: Development of the servant organizational leadership assessment (SOLA) instrument. Unpublished Ph. D. Thesis. Florida Atlantic University.

Liden, R. C., Wayne, S. J. Zhao, H. ve Henderson, D. (2008), Servant leadership: Development of a multidimensional measure and multi-level assessment, The Leadership Quarterly, 19(2), 161-177.

Page, D. ve Wong, T. P. (2000). A conceptual framework for measuring servant leadership. In S. Adjibolosoo (Ed.), The Human Factor In Shaping The Course of History and Developmentiçinde (s.1-28), Oxford: University Press of America.

Patterson, K. (2003). Servant leadership: A theoretical model. Servant Leadership Research Roundtable. Regent University School of Leadership Studies. 12 Nisan 2020 tarihinde http://www.regent.edu/acad/global/publications Lsl proceedings/2003/patterson servant leadership.pdf adresinden erişildi.

Spears, L. C. (1998). Insights on leadership: Service, stewardship, spirit, and servantleadership. New York: Wiley and Sons.

Spears, L. C. (2002). Focus on leadership: Servant-leadership for the twenty-first century. L. C. Spears and M. Lawrence (Eds.), focus on leadershipiçinde (s.119). New York: John Wiley And Sons, Inc.

Spears, L. C. (2010). Character and servant leadership: Ten characteristics of effective, caring leaders. The Journal of Virtues ve Leadership, 1(1), 25-30.

Şencan, H. (2005). Sosyal ve davranışsal ölçümlerde güvenilirlik ve geçerlilik. Ankara: Seçkin Yayıncllı.

Şimşek, Ö. F. (2007). Yapısal eşitlik modellemesine giriş. Ankara: Ekinoks Yayıncılık.

Tavşancıl, E. (2010). Tutumların ölçülmesi ve SPSS ile veri analizi. Ankara: Nobel Yayın Dağıtım.

Tezbaşaran, A. A. (1997). Likert tipi ölçek geliştirme kllavuzu. Ankara: Türk Psikologlar Derneği.

Trompenaars, F. ve Voerman, E. (2009). Servant-leadership across cultures: Harnessing the strengths of the world's most powerful management philosophy. New York: The McGraw-Hill Companies.

Vinod, S. ve Sudhakar, B. (2011). Servant leadership: A unique art of leadership, Interdisciplinary Journal of Contemporary Research in Business, 2(11), 456-467.

Yilmaz, V. ve Çelik, H. E. (2009). Lisrel ile Yapısal Eşitlik ModellemesiI Temel Kavramlar, Uygulamalar, Programlama. Ankara: Pegem Akademi Yayıncllk. 


\section{Kaynakça Bilgisi / Citation Information}

Yücedağ Erdinç, N. ve Kahyaoğlu Yaman, D.(2020).Kuşak farklılıklarına göre finansal okuryazarlık düzeyinin belirlenmesi: sağlık çalışanları üzerine bir araştırma. OPUS-Uluslararası Toplum Araştırmaları Dergisi, 16(30),2478-2503.DOI: 10.26466/opus.748393 